\title{
The Natural History of Ductal Carcinoma In Situ of the Breast - An Overview
}

\author{
Hanna Fredholm ${ }^{1,2}$, Amelia Chiorescu ${ }^{1,2}$, Irma Fredriksson ${ }^{1,2}$, Helena Sackey ${ }^{1,2}$ \\ 'Department of Molecular Medicine and Surgery, Karolinska Institutet, Stockholm, Sweden \\ ${ }^{2}$ Department of Breast, Endocrine tumors and Sarcoma, Karolinska University Hospital, Stockholm, Sweden
}

*Corresponding author: Hanna Fredholm MD, PhD Department of Molecular Medicine and Surgery, Karolinska Institutet, Stockholm, Sweden

E-Mail: hanna.fredholm@ki.se

\section{Rezumat}

Carcinomul mamar ductal in situ (CDIS) reprezintă o patologie heterogenă a cărei evoluție este dificil de documentat având în vedere că excizia chirurgicală se face de rutină. Studii ce descriu leziuni incomplet excizate considerate benigne după biopsie, dar care la o reevaluare ulterioară au fost diagnosticate CDIS, oferă anumite informații legate de evoluția bolii. Rezumând aceste date retrospective, $14-53 \%$ din cazurile ulterior diagnosticate CDIS au progresat către carcinom mamar invaziv. În timp ce observatiiile date de reevaluarea retrospectivă a biopsiilor şi autopsiilor aduc informații epidemiologice suplimentare pentru a înțelege evoluția bolii, cele mai importante rezultate sunt încă aşteptate din studii prospective, cu urmărire activă a pacienților cu CDIS. Aceste studii vor aduna date despre caracteristicile pacienților, precum stilul de viață si factorii de mediu, dar şi date genomice şi metabolomice tumorale şi stromale, ce vor putea eventual să elucideze istoria naturală a bolii şi cum va putea fi tratată în viitor.

Cuvinte cheie: istorie naturală, cancer de sân, progresie, carcinom ductal in situ

\begin{abstract}
Ductal carcinoma in situ (DCIS) of the breast is a heterogenous disease and its natural history cannot be directly observed as surgical removal is part of the current standard of care. Studies of incompletely excised breast lesions that were considered benign after biopsy, but at review years later were recognized as DCIS, offers some insight to the natural history of DCIS. Summarizing these retrospective data; $14-53 \%$ of the cases retrospectively
\end{abstract}


diagnosed as DCIS progressed to invasive breast cancer (IBC) during follow-up. While observations from retrospective re-evaluation of biopsies and autopsies adds epidemiological input for understanding the natural history of DCIS, the most important results are still awaited from the ongoing prospective studies on active surveillance of DCIS. These studies with collected data on patient characteristics, life-style and environmental factors, as well as tumor and stromal metabolomics and genomics, will probably further elucidate the natural history of DCIS and how the disease should be treated in the future.

Key words: natural history, breast cancer, progression, ductal carcinoma in situ

\section{Introduction}

Ductal carcinoma in situ (DCIS) constitutes a spectrum of preinvasive lesions with a broad spectrum of malignant potential and can rapidly progress to invasive breast cancer (IBC), may change very slowly or never end-up in an IBC. The transition is poorly understood and it is unclear if genetic changes and clonal selection give rise to a subpopulation of neoplastic cells with the ability to penetrate the basement membrane and cause spread to the surrounding tissue, or if changes in the myoepithelial, myofibroblastic and fibroblastic cells in the DCIS microenvironment give them this ability. Existent evidence supports a combination of the two models (1).

Despite DCIS being a preinvasive lesion, and though a considerable proportion of DCIS probably never would progress to IBC, women diagnosed with DCIS will get a breast cancer treatment not differing much from that given at diagnosis of an IBC; including breast conserving surgery and adjuvant radiotherapy or mastectomy, and in some countries also adjuvant endocrine therapy. Studies on health-related quality of life in women with DCIS show that despite an excellent prognosis, women diagnosed with DCIS overestimate their risk of invasive recurrence (2) and distant metastatic disease (3) and have a decline in mental health and social functioning the first 6 months after diagnosis (4). An ability to identify which DCIS lesions that most likely will progress to IBC, and over what time frame, would have a great impact on treatment selection and might offer a possibility to de-escalate treatment in selected patients.

Incidence rates of DCIS have been rising from the pre-mammographic era of the 1970s when it accounted for less than $5 \%$ of all breast cancers $(5,6)$ until today, when it accounts for about one fifth to one fourth of all newly diagnosed breast cancers, with a variation in incidence between countries, with the lowest proportion noted in Finland (9\%) and the highest in the US (24\%) (7). DCIS is a heterogenous disease and its natural history cannot be directly observed as surgical removal is part of the current standard of care. However, there are studies of incompletely excised breast lesions, lesions that were considered benign after biopsy but at review years later were recognized as DCIS, which offers some insight in the natural history of DCIS (8-12). The aim of this article is to give an overview of current knowledge and common hypotheses regarding the natural history of DCIS.

\section{Methods}

We conducted a survey in the PubMed database (citations for biomedical literature from MEDLINE, life science journals and online books) identifying relevant publications including follow-up studies of DCIS initially misdiagnosed as benign, biopsy-only studies 
where cases with DCIS were left un-treated, autopsy studies, and studies using models to study growth of DCIS and progression to IBC.

\section{Aspects on the Natural History of DCIS}

\section{Basic Histopathology}

DCIS is characterized by the proliferation of malignant ductal epithelial cells that lack the ability to penetrate the basement membrane and thereby lack the capacity to metastasize (13-15). Whether all IBC go through a potentially detectable phase of DCIS or whether some cell populations have the ability to invade the surrounding stroma directly, is unknown.

The American surgical pathologist Broders was the first to define the term and the general concept of carcinoma in situ in 1932 and thereby changed the very definition of cancer (16). One of the earliest and most well-known studies on the progression of DCIS to IBC was published in 1973 by Wellings et al analyzing 60 human breasts. They observed the smallest solitary, independent foci of DCIS in the terminal duct lobular units (TDLUs) (17), and hypothesized that DCIS usually arises in the TDLUs rather than in larger ducts, and that there is a continuous, but not obligatory, progression to IBC over a long period of time and through a series of gradually more malignification: ductal hyperplasia, atypical ductal hyperplasia $(\mathrm{ADH})$ and DCIS.

Indirect evidence that DCIS is a precursor of IBC is represented by the fact that DCIS and IBC commonly co-exists within one breast cancer lesion (18), and that approximately 50 $\%$ of all DCIS recurrences following breast conserving surgery, as well as the vast majority after a mastectomy, will be an invasive cancer (19-24). IBC and DCIS co-existing in the same lesion do often, but not always, share similar genetic profiles and histopathological and immunohistochemical appearance, supporting the theory of a common origin (25-29). The same is true for an invasive recurrence after a primary DCIS.

DCIS develops along a chain of changes starting within the normal breast cell, going through multiple histological and biological changes including multiple chromosomal losses or gains, as hyperplastic lesions progress through ADH and DCIS to IBC (30-32). Loss of heterozygosity for example, is noted in more than $70 \%$ of high-grade DCIS, in $\mathrm{ADH}$ in approximately $35 \%$ but not at all in normal breast tissue $(31,33)$. Most changes in gene expression seems to happen early in the chain of progression and a majority during the transitional phase from normal tissue to DCIS (27,34-37).

An alternative theory to the above model that normal epithelial breast cells, trough genetic changes and clonal selection give rise to a subpopulation of malignant cells with the capacity to penetrate the basement membrane, is the so-called release model hypothesizes. This theory hypothesizes that changes in the DCIS microenvironment such as phenotypic changes of myofibroblastic, myoepithelial, and fibroblastic cells and the infiltration of inflammatory cells lead to the disruption of the basement membrane and the ability to metastasize. Most likely, a combination of these two models contributes to the progression to IBC (38).

There is a good agreement, although not perfect, between DCIS and IBC in the same lesion with regard to tumor grade, estrogen receptor (ER)-, HER2- and p53 status (30,39, 40). When comparing the genetic and immunohistochemical profiles of DCIS with those of IBC there are concordant findings between high-grade DCIS and high-grade IBC, and between low-grade DCIS and low-grade IBC $(39,41)$, indicating that low-grade DCIS progress to low-grade IBC and high-grade DCIS to high-grade IBC, with intermediategrade DCIS representing an intermediate behavior. ER expression in DCIS is inversely related to nuclear grade and more than $90 \%$ of low-grade DCIS are ER positive and less than $20 \%$ exhibit overexpression of HER2 or p53 mutations. In contrast, only $25 \%$ of high-grade DCIS are ER positive while overexpression of HER2 or p53 mutations are seen in over $60 \%$ (42-44). Several studies show that the most clinically relevant features of IBC, such as ERand HER2- status as well as nuclear grade, are 
determined by the time the DCIS has evolved suggesting that IBC tumor characteristics may be determined by the characteristics of the precursive DCIS $(27,37,45)$. The importance and clinical utility of ER in DCIS presented in studies (46-48) has led to updated recommendations in the ASCO/CAP Guidelines, stipulating that all newly diagnosed pure DCIS lesions should be tested for ER to determine the potential benefit of endocrine treatment in reducing the risk of a future IBC (49).

\section{Biopsy Studies}

There are at least five studies on untreated DCIS cases published the latest four decades, which have added important information on the natural history of DCIS and its propensity to progress to IBC (8-12). These studies have the same setting; large series of historical breast biopsies, initially diagnosed as benign, that later were re-evaluated with a finding of DCIS. Any clinically detected breast cancer event during follow-up was recorded. The evaluated series included between 1877 and 26539 biopsies and were performed between 1940 and 1991 with length of follow-up between 15 and 26 years. The indication for original diagnostic biopsies were in the premammography era (1940-1950) a palpable mass (9). In the most recent study biopsies were taken between 1973 and 1991, the indication for biopsy was quite evenly distributed between a palpable mass and a mammographic finding (8). One study report the initial benign diagnoses of the biopsies later re-evaluated as DCIS; the most common diag- noses were fibrocystic disease, intraductal hyperplasia and atypical intraductal papillomatosis followed by $\mathrm{ADH}$ and atypical lobular hyperplasia (8). The most common architectural pattern of the misdiagnosed DCIS cases was the cribriform (33\% and $54 \%$ ) followed by the solid growth pattern (24\% and $23 \%$ ) (8, 11). All five studies together collected more than 57600 biopsies with findings of 196 cases of DCIS at review with a summarized incidence of a later IBC of $27.0 \%$ (48 IBC in the 178 DCIS cases with follow-up data) (8-12). Later IBC were in four studies ipsilateral in all cases (8,10-12) and in $75 \%$ in one study (9). Summarizing these retrospective data; $14-53$ $\%$ of the cases retrospectively diagnosed as DCIS progressed to IBC during follow-up (Table 1). However, these case studies are difficult to draw conclusions from regarding the propensity of DCIS to progress; one can not rule out that the mis-diagnosed DCIS more often may have been of low grade with a supposed longer time to being clinically detected than another case of high grade DCIS, and that some of the cases in the biopsy only studies, may have been cured by the biopsy preformed.

\section{Autopsy Studies}

In theory, the prevalence of DCIS diagnosed in autopsy studies and a comparison with clinically diagnosed DCIS in the general population provide further knowledge into the proportion of DCIS that may not become clinically significant. In one study from Copenhagen, published in 1987, 110 medicolegal autopsies were done on women aged 20-

Table 1. Five studies published during the last four decades on DCIS found at re-evaluation of benign breast biopsies

\begin{tabular}{lccccccc}
\hline First author & $\begin{array}{c}\text { Publication } \\
\text { year }\end{array}$ & $\begin{array}{c}\text { Period of } \\
\text { biopsy }\end{array}$ & $\begin{array}{c}\text { Follow-up } \\
\text { (years) }\end{array}$ & $\begin{array}{c}\text { No. of } \\
\text { biopsies }\end{array}$ & $\begin{array}{c}\text { No. of DCIS } \\
\text { (with FU) }\end{array}$ & $\begin{array}{c}\text { No. of DCIS with } \\
\text { later IBC event }\end{array}$ & $\begin{array}{c}\text { Frequency of } \\
\text { later IBC event }\end{array}$ \\
\hline Rosen (10) & 1980 & $1940-1950$ & 18 (mean) & $>8000$ & $30(15)$ & 8 & $53.3 \%$ \\
\hline Page (12) & 1982 & $1950-1968$ & 15 & 11,760 & $28(25)$ & 7 & $28.0 \%$ \\
\hline Eusebi (9) & 1994 & $1964-1976$ & 17.5 (mean) & 9446 & $80(80)$ & 11 & $13.8 \%$ \\
\hline Collins (8) & 2000 & $1973-1991$ & missing & 1877 & $13(13)$ & 6 & $46.2 \%$ \\
\hline Sanders (11) & 2015 & $1950-1989$ & 26 (median) & 26,539 & $45(45)$ & 16 & $35.6 \%$ \\
\hline DCS (d)
\end{tabular}

DCIS (ductal carcinoma in situ), No. (number), FU (follow-up), IBC (invasive breast cancer). 
54 (of which one had an earlier treated IBC). Breast cancer was found in 22 women (20\%), of which two had IBC (2\%) and 15 a DCIS (14 $\%)(50)$. A lower incidence of DCIS was found in an autopsy study from the US published in 1985, where 185 breast specimens were examined and 11 diagnosed with DCIS (5.9\%). In a review article including seven autopsy studies published between 1973 and 1987, data were compiled including altogether 852 women not earlier diagnosed with breast cancer; here the median prevalence of DCIS was $8.9 \%$ (range $0-14.7 \%$ ) and of IBC $1.3 \%$ (0-1.8\%). Three of the included studies reported a prevalences of DCIS in women of screening age; $10 \%$ in women aged 50-70 years, $13 \%$ in women aged $40-70$ years and 39 $\%$ in women aged 40-49 years (51). A more recently published meta-analysis, including 13 studies from 1948 to 2010 and totally 2363 women, the estimated mean prevalence of undiagnosed breast cancer or precursor lesion was $19.5 \%(0.85 \%$ IBC, $8.9 \%$ in situ cancer and $9.8 \% \mathrm{ADH}$ ) (52). In both these studies the observed prevalence of undiagnosed lobular and ductal in situ cancer were $8.9 \%$, whereas undiagnosed IBC was less common. These data suggest that a large undetected reservoir of DCIS exist in the population, lesions that might never become clinically significant. However, these data should be interpreted with caution as the prevalence estimates originates from studies published prior to current stringent criteria to distinguish between $\mathrm{ADH}$ and DCIS (53-55).

\section{Modeling the Natural History of DCIS}

Another way to elucidate the natural history of DCIS has been to design simulating models to estimate the progression to IBC. Mathematical models developed for estimation of IBC growth rate (56) are nevertheless not optimal for DCIS as they depend on tumor volume and a concentric expansion of the tumor, not applicable in DCIS due to the more scattered growth pattern. Considering that DCIS tumors more often are longer in the axial direction than in the radial direction, thereby assuming a linear growth (57); Franks et al. developed a mathematical model to describe when the intra-ductal cancer cells starts to invade the duct cell membrane based on the viscosity of the tumor, the concentration of live and dead tumor cells and nutrientlimited growth (58). An example of a less complex mathematical model is the one by Kopans et al. (59) built on the assumption that DCIS progress with a constant, pre-defined growth rate for a clone; doubling it's size in 60, 120 or 180 days. Using the assumptions, the model showed that for every three breast tumors that get clinically detectable (when reaching a size of approximately $2 \mathrm{~cm}$ ), there would be another 57 tumors that still are undetected (39 invasive and 18 DCIS).

Models based on population data focus mainly on the risk of DCIS progressing into IBC. In a study comparing two validated Norwegian and a Dutch population models, 30 $\%, 50 \%$ or $80 \%$ of DCIS cases were assumed to proceed into IBC. Whether accounting for DCIS regression or not, the majority of screendetectable, preclinical DCIS left without surgical excision, progressed to IBC (64-100\% in submodels assuming no DCIS regression and $36-100 \%$ in submodels allowing for DCIS regression) (60). The mean sojourn time (time from preclinical DCIS to IBC) was relatively short; 0.2 to 2.5 years (60).

\section{Prospective Studies on the Natural History of DCIS}

While there are valid data on the necessity of radical surgery in high grade DCIS (61), three trials has started the last decade including women with low grade DCIS where active surveillance is an option. The Dutch LORD study are enrolling a total of 2500 partici- $^{-}$ pants, started in 2017 and are planned to be complete in 2029 (62). The study is recruiting women aged $>45$ years with screen-detected DCIS grade I-II to either active surveillance with annual digital mammography at year 1-5, 7 and 10, or standard treatment (wide local excision (WLE) only, WLE plus radiotherapy or mastectomy \pm endocrine treatment). 
Primary outcome is invasive breast cancer free survival.

The British LORIS study is a phase III, randomised controlled trial comparing surgery with active monitoring for low risk DCIS recruiting 932 women $\geq 46$ years with a primary diagnosis of a screen-detected, nonhigh-grade DCIS in 2014 to 2020, without nipple discharge or major family history (63). All participants are followed with an annual mammography for 10 years. Primary outcome is ipsilateral invasive breast cancer free survival.

The COMET trial is a randomised controlled phase III trial conducted in the United States comparing guideline concordant care (surgery, radiotherapy, endocrine therapy) with active surveillance \pm endocrine treatment (64). The study started in 2018 and are planned to recruit 1200 women $\geq 40$ years with low-risk DCIS and without previous DCIS or invasive breast cancer 5 years prior inclusion. Mammography will be performed every 6 months in the active monitoring arm and every 12 months in the surgical arm during 10 years of follow-up. Primary outcome is ipsilateral invasive breast cancer free survival.

PRECISION (PREvent ductal Carcinoma In Situ Invasive Overtreatment Now) is an international initiative building on multiple studies of DCIS by integrating clinical, pathological, imaging and molecular data in large wellannotated cohorts of DCIS samples aiming to develop a risk prediction model to distinguish indolent from aggressive DCIS (65).

\section{Conclusion}

From being a rare finding in mastectomy specimens when first defined almost a century ago; the incidence of DCIS has exploded since the introduction of mammography screening and accounts for a substantial part of all breast cancer cases diagnosed today. Treatment of DCIS has intensified over the last decades, improving the local recurrence rate but without any impact on overall or disease-specific survival. While observations from retrospective re-evaluation of biopsies and autopsies adds epidemiological input for understanding the natural history of DCIS, the most important results are still awaited from the ongoing prospective studies on active surveillance of DCIS. These studies with collected data on patient characteristics, lifestyle, and environmental factors, as well as tumor and stromal metabolomics and genomics, will probably further elucidate the natural history of DCIS and how DCIS should be treated in the future.

\section{Conflict of Interest}

The authors declare no conflicts of interests.

\section{References}

1. Sgroi DC. Preinvasive breast cancer. Annu Rev Pathol. 2010;5:193-221.

2. Partridge A, Adloff K, Blood E, Dees EC, Kaelin C, Golshan M, et al. Risk perceptions and psychosocial outcomes of women with ductal carcinoma in situ: Iongitudinal results from a cohort study. I Natl Cancer Inst. 2008;100(4):243-51.

3. Hawley ST, Janz NK, Griffith KA, Jagsi R, Friese CR, Kurian AW, et al. Recurrence risk perception and quality of life following treatment of breast cancer. Breast Cancer Res Treat. 2017;161(3):557-65.

4. Nekhlyudov L, Kroenke CH, Jung I, Holmes MD, Colditz GA. Prospective changes in quality of life after ductal carcinoma-in-situ: results from the Nurses' Health Study. J Clin Oncol. 2006;24(18):2822-7.

5. Rosner D, Bedwani RN, Vana J, Baker HW, Murphy GP. Noninvasive breast carcinoma: results of a national survey by the American College of Surgeons. Ann Surg. 1980;192(2):139-47.

6. Smart CR, Myers MH, Gloeckler LA. Implications from SEER data on breast cancer management. Cancer. 1978;41(3):787-9.

7. Lynge E, Ponti A, James T, Majek 0, von Euler-Chelpin M, Anttila A, et al. Variation in detection of ductal carcinoma in situ during screening mammography: a survey within the International Cancer Screening Network. Eur J Cancer. 2014;50(1):185-92.

8. Collins LC, Tamimi RM, Baer HJ, Connolly JL, Colditz GA, Schnitt SJ. Outcome of patients with ductal carcinoma in situ untreated after diagnostic biopsy: results from the Nurses' Health Study. Cancer. 2005;103(9): 1778-84.

9. Eusebi V, Feudale E, Foschini MP, Micheli A, Conti A, Riva C, et al. Longterm follow-up of in situ carcinoma of the breast. Semin Diagn Pathol. 1994;11(3):223-35.

10. Rosen PP, Braun DW, Jr., Kinne DE. The clinical significance of pre-invasive breast carcinoma. Cancer. 1980;46(4 Suppl):919-25.

11. Sanders ME, Schuyler PA, Simpson JF, Page DL, Dupont WD. Continued observation of the natural history of low-grade ductal carcinoma in situ reaffirms proclivity for local recurrence even after more than 30 years of follow-up. Mod Pathol. 2015;28(5):662-9.

12. Page DL, Dupont WD, Rogers LW, Landenberger M. Intraductal carcinoma of the breast: follow-up after biopsy only. Cancer. 1982;49(4):751-8.

13. Cowell CF, Weigelt B, Sakr RA, Ng CK, Hicks J, King TA, et al. Progression from ductal carcinoma in situ to invasive breast cancer: revisited. Mol Oncol. 2013;7(5):859-69.

14. Lopez-Garcia MA, Geyer FC, Lacroix-Triki M, Marchio C, Reis-Filho JS. Breast cancer precursors revisited: molecular features and progression pathways. Histopathology. 2010;57(2):171-92.

15. Place AE, Jin Huh S, Polyak K. The microenvironment in breast cancer 
progression: biology and implications for treatment. Breast Cancer Res. 2011;13(6):227.

16. Broders AC. Carcinoma in situ contrasted with benign penetrating epithelium. Journal of the American Medical Association. 1932;99(20):1670-4.

17. Wellings SR, Jensen HM. On the origin and progression of ductal carcinoma in the human breast. J Natl Cancer Inst. 1973;50(5):1111-8,

18. Fisher ER, Gregorio RM, Fisher B, Redmond C, Vellios F, Sommers SC. The pathology of invasive breast cancer. A syllabus derived from findings of the National Surgical Adjuvant Breast Project (protocol no. 4). Cancer. 1975:36(1):1-85.

19. Frykberg ER, Bland KI. Overview of the biology and management of ductal carcinoma in situ of the breast. Cancer. 1994;74(1 Suppl):350-61.

20. Boyages J, Delaney G, Taylor R. Predictors of local recurrence after treatment of ductal carcinoma : a meta-analysis. Cancer. 1999;85(3):616-28.

21. Greenberg CC, Habel LA, Hughes ME, Nekhlyudov L, Achacoso N, Acton L, et al. Characterization and treatment of local recurrence following breast conservation for ductal carcinoma in situ. Ann Surg Oncol. 2014;21(12): 3766-73.

22. Collins LC, Achacoso N, Haque R, Nekhlyudov L, Fletcher SW, Quesenberry $\mathrm{CP}$, Jr., et al. Risk factors for non-invasive and invasive local recurrence in patients with ductal carcinoma in situ. Breast Cancer Res Treat. 2013; 139(2):453-60

23. Mamtani A, Nakhlis F, Downs-Canner S, Zabor EC, Morrow M, King TA, et al. Impact of Age on Locoregional and Distant Recurrence After Mastectomy for Ductal Carcinoma In Situ With or Without Microinvasion. Ann Surg Oncol. 2019;26(13):4264-71.

24. Owen D, Tyldesley S, Alexander C, Speers C, Truong P, Nichol A, et al. Outcomes in patients treated with mastectomy for ductal carcinoma in situ. Int J Radiat Oncol Biol Phys. 2013;85(3):e129-34.

25. Radford DM, Phillips NJ, Fair KL, Ritter JH, Holt M, Donis-Keller H. Allelic loss and the progression of breast cancer. Cancer Res. 1995;55(22):5180-3.

26. Aubele M, Mattis A, Zitzelsberger $\mathrm{H}$, Walch A, Kremer M, Welzl G, et al. Extensive ductal carcinoma In situ with small foci of invasive ductal carcinoma: evidence of genetic resemblance by CGH. Int J Cancer. 2000; 85(1):82-6.

27. Buerger $H$, Otterbach F, Simon R, Schafer KL, Poremba C, Diallo R, et al. Different genetic pathways in the evolution of invasive breast cancer are associated with distinct morphological subtypes. J Pathol. 1999;189(4): 521-6.

28. Steinman S, Wang J, Bourne P, Yang Q, Tang P. Expression of cytokeratin markers, ER-alpha, PR, HER-2/neu, and EGFR in pure ductal carcinoma in situ (DCIS) and DCIS with co-existing invasive ductal carcinoma (IDC) of the breast. Ann Clin Lab Sci. 2007;37(2):127-34.

29. Tamimi RM, Baer HJ, Marotti J, Galan M, Galaburda L, Fu Y, et al. Comparison of molecular phenotypes of ductal carcinoma in situ and invasive breast cancer. Breast Cancer Res. 2008;10(4):R67.

30. Allred DC, Mohsin SK, Fuqua SA. Histological and biological evolution of human premalignant breast disease. Endocr Relat Cancer. 2001:8(1):47-61.

31. Aubele MM, Cummings MC, Mattis AE, Zitzelsberger HF, Walch AK, Kremer $\mathrm{M}$, et al. Accumulation of chromosomal imbalances from intraductal proliferative lesions to adjacent in situ and invasive ductal breast cancer. Diagn Mol Pathol. 2000;9(1):14-9.

32. Zhuang Z, Merino MJ, Chuaqui R, Liotta LA, Emmert-Buck MR. Identical allelic loss on chromosome 11 113 in microdissected in situ and invasive human breast cancer. Cancer Res. 1995;55(3):467-71.

33. O'Connell P, Pekkel V, Fuqua SA, Osborne CK, Clark GM, Allred DC. Analysis of loss of heterozygosity in 399 premalignant breast lesions at 15 genetic loci. J Natl Cancer Inst. 1998;90(9):697-703.

34. Porter DA, Krop IE, Nasser S, Sgroi D, Kaelin CM, Marks JR, et al. A SAGE (serial analysis of gene expression) view of breast tumor progression. Cancer Res. 2001;61(15):5697-702.

35. Porter D, Lahti-Domenici J, Keshaviah A, Bae YK, Argani P, Marks J, et al. Molecular markers in ductal carcinoma in situ of the breast. Mol Cancer Res. 2003;1(5):362-75.

36. Castro NP, Osorio CA, Torres C, Bastos EP, Mourao-Neto M, Soares FA, et al. Evidence that molecular changes in cells occur before morphological alterations during the progression of breast ductal carcinoma. Breast Cancer Res. 2008;10(5):R87.
37. Gupta SK, Douglas-Jones AG, Fenn N, Morgan JM, Mansel RE. The clinical behavior of breast carcinoma is probably determined at the preinvasive stage (ductal carcinoma in situ). Cancer. 1997;80(9):1740-5.

38. Polyak K, Hu M. Do myoepithelial cells hold the key for breast tumor progression? J Mammary Gland Biol Neoplasia. 2005;10(3):231-47.

39. Douglas-Jones AG, Gupta SK, Attanoos RL, Morgan JM, Mansel RE. A critical appraisal of six modern classifications of ductal carcinoma in situ of the breast (DCIS): correlation with grade of associated invasive carcinoma. Histopathology. 1996;29(5):397-409.

40. Warnberg $\mathrm{F}$, Nordgren $\mathrm{H}$, Bergkvist $\mathrm{L}$, Holmberg L. Tumour markers in breast carcinoma correlate with grade rather than with invasiveness. $\mathrm{Br} \mathrm{J}$ Cancer. 2001;85(6):869-74.

41. Puvanesarajah S, Gapstur SM, Gansler T, Sherman ME, Patel AV, Gaudet MM. Epidemiologic risk factors for in situ and invasive ductal breast cancer among regularly screened postmenopausal women by grade in the Cancer Prevention Study-II Nutrition Cohort. Cancer Causes Control. 2020; 31(1):95-103.

42. DiGiovanna MP, Chu P, Davison TL, Howe CL, Carter D, Claus EB, et al. Active signaling by HER-2/neu in a subpopulation of HER-2/neu-overexpressing ductal carcinoma in situ: clinicopathological correlates. Cancer Res. 2002;62(22):6667-73.

43. Di Cesare P, Pavesi L, Villani L, Battaglia A, Da Prada GA, Riccardi A, et al. The Relationships between HER2 Overexpression and DCIS Characteristics. Breast J. 2017;23(3):307-14

44. Walker RA, Hanby A, Pinder SE, Thomas J, Ellis I0, National Coordinating Committee for Breast Pathology Research S. Current issues in diagnostic breast pathology. J Clin Pathol. 2012;65(9):771-85.

45. Rudnicka L, Stachura J. Correlation between type and grade of ductal carcinoma in situ and concomitant invasive ductal carcinoma of the breast. Pol J Pathol. 2000;51(3):137-43.

46. Allred DC, Anderson SJ, Paik S, Wickerham DL, Nagtegaal ID, Swain SM, et al. Adjuvant tamoxifen reduces subsequent breast cancer in women with estrogen receptor-positive ductal carcinoma in situ: a study based on NSABP protocol B-24. J Clin Oncol. 2012;30(12):1268-73.

47. DeCensi A, Puntoni M, Guerrieri-Gonzaga A, Caviglia S, Avino F, Cortesi L, et al. Randomized Placebo Controlled Trial of Low-Dose Tamoxifen to Prevent Local and Contralateral Recurrence in Breast Intraepithelial Neoplasia. J Clin Oncol. 2019;37(19):1629-37.

48. Hwang KT, Kim EK, Jung SH, Lee ES, Kim SI, Lee S, et al. Tamoxifen therapy improves overall survival in luminal A subtype of ductal carcinoma in situ: a study based on nationwide Korean Breast Cancer Registry database. Breast Cancer Res Treat. 2018;169(2):311-22.

49. Allison KH, Hammond MEH, Dowsett M, McKernin SE, Carey LA, Fitzgibbons PL, et al. Estrogen and Progesterone Receptor Testing in Breast Cancer: ASCO/CAP Guideline Update. J Clin Oncol. 2020;38(12):1346-66.

50. Nielsen M, Thomsen JL, Primdahl S, Dyreborg U, Andersen JA. Breast cancer and atypia among young and middle-aged women: a study of 110 medicolegal autopsies. Br J Cancer. 1987;56(6):814-9.

51. Welch HG, Black WC. Using autopsy series to estimate the disease "reservoir" for ductal carcinoma in situ of the breast: how much more breast cancer can we find? Ann Intern Med. 1997;127(11):1023-8.

52. Thomas ET, Del Mar C, Glasziou P, Wright G, Barratt A, Bell KJL. Prevalence of incidental breast cancer and precursor lesions in autopsy studies: a systematic review and meta-analysis. BMC Cancer. 2017;17(1):808.

53. Dauplat MM, Penault-Llorca F. [Classification of preinvasive breast and carcinoma in situ: doubts, controversies, and proposal for new categorizations]. Bull Cancer. 2004;91 Suppl 4:S205-10.

54. Van de Vijver MJ, Peterse $\mathrm{H}$. The diagnosis and management of pre-invasive breast disease: pathological diagnosis--problems with existing classifications. Breast Cancer Res. 2003:5(5):269.

55. Ellis I0, Pinder SE, Lee AH, Elston CW. A critical appraisal of existing classification systems of epithelial hyperplasia and in situ neoplasia of the breast with proposals for future methods of categorization: where are we going? Semin Diagn Pathol. 1999;16(3):202-8.

56. Hart $\mathrm{D}$, Shochat $\mathrm{E}$, Agur $Z$. The growth law of primary breast cancer as inferred from mammography screening trials data. $\mathrm{Br} \mathrm{J}$ Cancer. 1998; 78(3):382-7. 
57. Fernandez-Gonzalez R, Jones A, Garcia-Rodriguez E, Chen PY, Idica A, Lockett SJ, et al. System for combined three-dimensional morphological and molecular analysis of thick tissue specimens. Microsc Res Tech. 2002; 59(6):522-30.

58. Franks SJ, Byrne HM, King JR, Underwood JC, Lewis CE. Modelling the early growth of ductal carcinoma in situ of the breast. J Math Biol. 2003; 47(5):424-52.

59. Kopans DB, Rafferty E, Georgian-Smith D, Yeh E, D'Alessandro H, Moore R, et al. A simple model of breast carcinoma growth may provide explanations for observations of apparently complex phenomena. Cancer. 2003; 97(12):2951-9.

60. Chootipongchaivat S, van Ravesteyn NT, Li X, Huang H, Weedon-Fekjaer H, Ryser MD, et al. Modeling the natural history of ductal carcinoma in situ based on population data. Breast Cancer Res. 2020;22(1):53.

61. Maxwell AJ, Clements K, Hilton B, Dodwell DJ, Evans A, Kearins 0, et al. Risk factors for the development of invasive cancer in unresected ductal carcinoma in situ. Eur J Surg Oncol. 2018;44(4):429-35.

62. Elshof LE, Tryfonidis K, Slaets L, van Leeuwen-Stok AE, Skinner VP, Dif N, et al. Feasibility of a prospective, randomised, open-label, international multicentre, phase III, non-inferiority trial to assess the safety of active surveillance for low risk ductal carcinoma in situ - The LORD study. Eur $\mathrm{J}$ Cancer. 2015:51(12):1497-510.

63. Francis A, Thomas J, Fallowfield L, Wallis M, Bartlett JM, Brookes C, et al. Addressing overtreatment of screen detected DCIS; the LORIS trial. Eur J Cancer. 2015;51(16):2296-303

64. Hwang ES, Hyslop T, Lynch T, Frank E, Pinto D, Basila D, et al. The COMET (Comparison of Operative versus Monitoring and Endocrine Therapy) trial: a phase III randomised controlled clinical trial for low-risk ductal carcinoma in situ (DCIS). BMJ Open. 2019;9(3):e026797.

65. PRECISION c. PREvent Carcinoma In Situ Invasive Overtreatment Now [Internet] The Netherlands2021 [Available from: https://www.dcisprecision.org/. 